\title{
The Amazonomachy on Attic and Tarantine Funerary Naiskoi
}

\author{
By Valeria Riedemann L. ${ }^{*}$
}

Funerary naiskoi of monumental size were unusual in fourth-century BC Attic funerary art, but the evidence shows that a similar type of building was more commonly produced in the West: architectural andrelief fragments alongside depictions of naiskoi on Apulian red-figure vases indicate that this type of templelike structure was also produced in Taranto. Relief decoration showing episodes of heroic myth and battles served to enhance the status of the dead in tomb iconography; being the Amazonomachy the single most popular subject on fourthcentury BCfunerary monuments. Today, it is widely accepted that the popularity of the subject is indebted to its presence in the Mausoleum at Halikarnassos and other eastern funerary monuments, but little has been said about the myth's connotations when placed in different geographic areas. This paper will explore the funerary uses of the Amazonomachy through both a contextual and an iconographic analysis of its presence on Attic and Tarantine funerary naiskoi.

\section{Introduction}

Funerary temple-like structures (naiskoi) of monumental size were rare in fourth-century BC Attic funerary art. ${ }^{1}$ The evidence shows that a similar type of building was more widespread in the West: fragments of funerary reliefs alongside depictions of naiskoi on Apulian red-figure vases indicate that this type of funerary building was also produced in Taranto, and perhaps in other places of Apulia. Different from naiskos-stelai, monumental funerary naiskoi resemble building architecture, and thus architectural features such as columns and a roof framed the free-standing sculpture inside of it. In addition, relief decoration showing episodes of heroic battle and myth served to enhance the status of the dead in tomb iconography. Among these, the Amazonomachy is the single most popular subject in fourth-century BC funerary monuments. Today, it is widely accepted that the popularity of the subject is indebted to its presence in the Mausoleum at Halikarnassos and other eastern funerary buildings, but little has been said about the myth's connotations when placed in different geographic areas. This paper will explore the funerary uses of the Amazonomachy through both a contextual and iconographic analysis of its presence in funerary naiskoi. I will specifically look at the subject in the Kallithea Monument and on the relief

\footnotetext{
*Associate Researcher, University of Oxford, UK, and Visiting Scholar, University of Washington, USA.

1. For the development of funerary naiskoi, see E. Lippolis "Tipologie e significati del monumento funerario nella cità ellenistica. Lo sviluppo del naiskos" ["The typology and significance of the funerary monument in the Hellenistic city. The development of the naiskos"], in Architetti, architettura e cità nel Mediterraneo orientale ellenistico. Atti del Convegno, Venezia (10-11 giugno 2005) (Milan, 2007), 82-102.
} 
sculptures from the necropolis of Taranto. Since scholarly studies on the uses of the subject on these monuments are limited, this paper aims at providing an updated interpretation of the existing evidence in the light ofa comparative analysis.

\section{Literature Review: Attic and Tarantine Funerary Naiskoi}

The sources tell us some relevant information about this subject. First, we know that the production of elaborated gravestones in Greek art had an abrupt end in 317 BC when Demetrius of Phaleron's restrictive law banned grave monuments and sculptured tombstones (Cic. Leg. 2.26.66). This constraint, however, did not necessarily affect the funerary traditions in the apoikiai as shown by the evidence found in various necropoleis elsewhere. Second, in his description of funerary practices at Skyon, Pausanias (2.7.2) writes:

"[the Sicyonians]... cover the body in the ground, and over it they build a basement of stone upon which they set pillars. Above these, they put something like the pediment of a temple. They add no inscription, except that they give the dead man's name without that of his father and bid him farewell".

Lastly, thanks to Polibius (8.28) we know that Taranto (ancient Taras) was full of tombs and that their dead were still buried within the city walls. Nevertheless, we can only guess that he may have seen some of the naiskoi which would have survived the destruction of $275 \mathrm{BC}$ and the sack of the city by the Romans in $209 \mathrm{BC}^{2}$ Consequently, from this literary evidence, it is possible to assume that1) the Tarantine funerary production continued for over a century in comparison with that of Athens, and 2) the monuments analysed here could well constitute an actual basis for Pausanias' and Polybius' descriptions despite not having their accounts on the buildings' sculptural programmes.

\section{Attic Funerary Naiskoi}

Funerary monuments with architectural features from Attica can be dated between 335 and $317 \mathrm{BC}$, before the anti-luxury decree aforementioned. ${ }^{3} \mathrm{~A}$ large number of reliefs from Athens and Attica of the fourth century BC survive. Marble grave reliefs (stelai) and statues are the most common type

2. For the city and the necropolis, see E. De Juliis, Taranto, (Bari: Edipuglia, 2000), 51-72. For an account of the history of Taranto, see L. Cerchiai, "Taranto", in The Greek Cities of Magna Graecia and Sicily, ed. L. Cerchiai, L. Jannelli, and F. Longo (Los Angeles: Getty Publications, 2004), 144-155.

3. The date is given by the fragment of the MarmorParium $(13,114)$ in Oxford. For a discussion about the efectiveness of this decree, see W. Geominy Die Florentiner Niobiden [The Florentine Niobids] (Bonn: [Theses], 1984), 241 and n. 638. See B.S. Ridgway, Hellenistic Sculpture I, 331-200 BC (Bristol: Bristol Classical Press, 1990), 30-31. 
of grave markers in Attic funerary art. Although less frequently, relief slabs decorating temple-like structures which were often crowned by pediments were also part of the repertoire. ${ }^{4}$ These belonged to the naiskos-type with columns affixed to the walls as we can observe in some of the finest Athenian funerary reliefs produced about $330 \mathrm{BC} .^{5}$ In fact, it is possible to observe an evolution from funerary reliefs to naiskoi structures in Attica in 340-330 BC, when a pediment crowns a podium with two full columns on top and a rear wall. This frame sheltered relief or painted figures of the deceased individuals. ${ }^{6}$ As time went by, these transformations allowed the stelai to become larger, thus conceding space for more figures. For example, an increase from 1.58 $\mathrm{m}$ in the Hegeso stele to $2.91 \mathrm{~m}$ in the Aristonautes naiskos-stele indicates that these funerary structures were becoming monumental. ${ }^{7}$ These monuments were usually placed in funerary precincts bordering the roads outside the city gates where people could read the inscribed names of the deceased and other family members as they made their way. The process towards monumentalization culminates with the introduction of free-standing sculpture, relegating the relief decoration to the podium or the metopes in the case of the Tarantine examples.

The best preserved of such funerary structures is the Kallithea Monument (ca. $320 \mathrm{BC}$ ), found in 1968 between Athens and Piraeus, near one gate of the North Wall. ${ }^{8}$ Only brief accounts on its architectural and sculptural elements have been published to date, first by Tsirivakos and then by Schmaltz. ${ }^{9}$ In the 1990s the monument's sculptures were stylistically analysed by Ridgway and Clairmont, among others. ${ }^{10}$ More recently, Steinhauer's account of the monument - if not at all complete- provides the most compelling description that includes photos of its restoration. However, a comprehensive study on the Kallithea Monument is yet to be done. ${ }^{11}$

4. For Attic gravestones, see C. Clairmont, Classical Attic Tombstones (Kilchberg: Akanthus, 1993); O. Palagia, "Commemorating the Dead: Grave Markers, Tombs, and Tomb Paintings, 400-30 BCE", in A Companion to Greek Architecture, ed. M. Miles (Wiley \& Sons, 2016), 374-389.

5. Athens, NM inv. 869 (Illisos); inv. 737 (Prokles and Prokleides); inv. 738 (Aristonautes). See B.S. Ridgway, Hellenistic Sculpture I, 331-200 BC, 1990, 34-35; N. Kaltsas, Sculpture in the National Archaeological Museum, Athens (Los Ageles: Getty Publications, 2002), 204, no. 410; E. Lippolis, "Tipologie e significati del monumento funerario nella cità ellenistica. Lo sviluppo del naiskos", 2007, 91.

6. On these transformations, see E. Lippolis, "Tipologie e significati del monumento funerario nella cità ellenistica. Lo sviluppo del naiskos", 2007, 90-93. For painted stelai, see B. Schmaltz 1983, 81-101.

7. Athens, NM inv. 3624 (Hegeso Stele). See E. Lippolis, "Tipologie e significati del monumento funerario nella cità ellenistica. Lo sviluppo del naiskos", 2007, 92.

8. Athens, Piraeus Museum inv. 4502.

9. E. Tsirivakos, "Eı $\delta ́ \sigma ı \varsigma \varsigma ~ \varepsilon \kappa ~ K \alpha \lambda \lambda \imath \theta \dot{\varepsilon} \alpha \varsigma^{\prime}$ ["News from Kallithea"]. AAA 1(1968), 35-36, fig. 1, 108-9, figs. 1-3; E. Tsirivakos, "Kallithea: Ergebnisse der Ausgrabung" ["Kallithea: Results of the excavation"]. AAA 4, no. 1(1971): 108-110; B. Schmaltz 1983, 141-142.

10. B.S. Ridgway, Hellenistic Sculpture I, 331-200 BC, 1990, 31-32; C. Clairmont, Classical Attic Tombstones (Kilchberg: Akanthus), 59, fig. 25; J. Boardman Greek Sculpture: The Late Classical Period (London: Thames and Hudson, 1995), 117-118.

11. See G. Steinhauer, The Archaeological Museum of Piraeus (Athens: Latsis Group, 2001), 305-309. More recently, E. Lippolis, "Tipologie e significati del monumento funerario nella cità ellenistica. Lo sviluppo del naiskos", 2007, 93; R. Belli Pasqua, "Architettura funeraria a Rodi in età ellenistica: documentazione locale e forme di contatto" ["Funerary 
The Kallithea Monumentis is about $8.30 \mathrm{~m}$ high and still retained traces of colour when found. Its architectural features with its relief sculptures must have been undoubtedly impressive in antiquity when viewed from a distance and nearby (Figure 1). Its current reconstruction at the Piraeus Museum shows that it consisted of a high limestone podium topped by an Amazonomachy frieze, of which three blocks have been recovered. The now plain band in the middle may have carried a painted frieze. In addition to the marble colours, there are vestiges of paint on the figures and the mouldings.

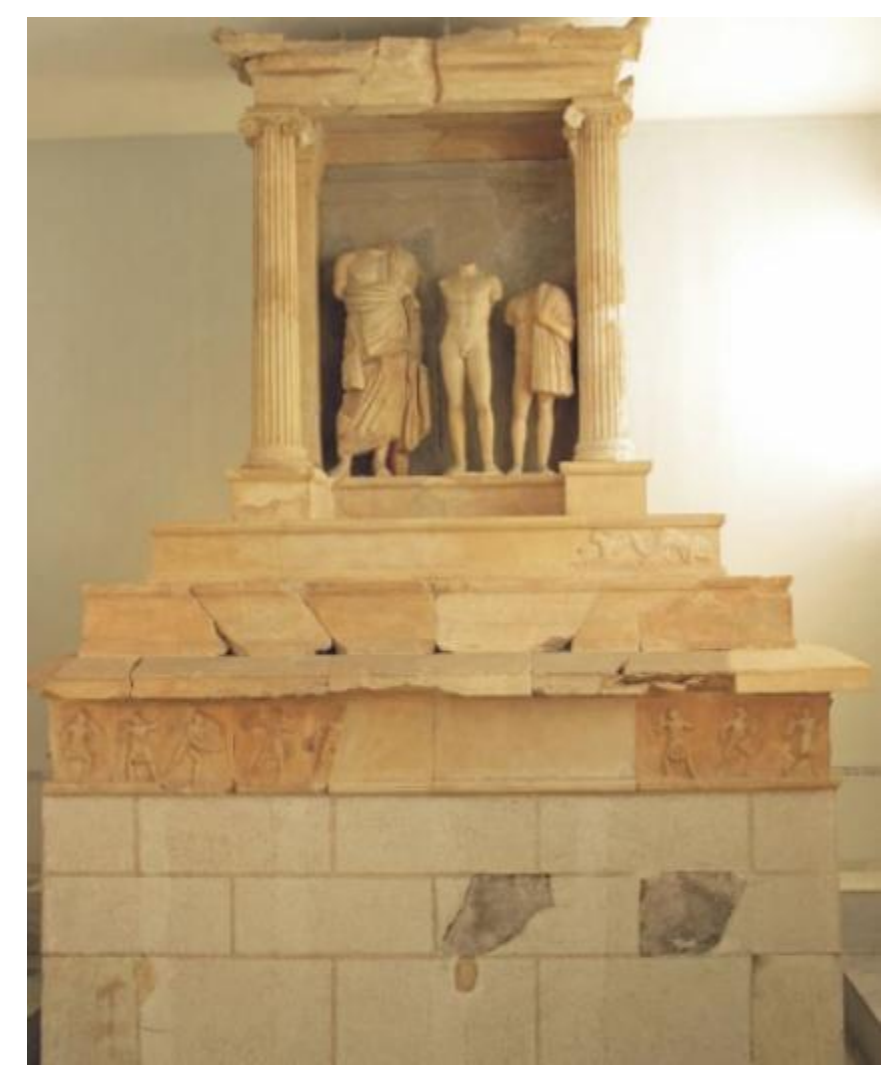

Figure 1. Piraeus Museum, Kallithea Monument Source: Olga Palagia, 2016, fig. 26.1.

The names of a father and his son, originally from Istria (modern Romania), are inscribed on the cornice over the Amazons frieze: Nikeratos son of Polyidos Istrianos and Polyxenos, son of Nikeratos. A smaller frieze with opposing animal groups survives in five blocks. Besides, two Ionic columns created a naiskos with a solid back wall made of grey Hymettian marble. Three statues of Pentelic marble, all headless now, stood inside this space. ${ }^{12}$ The group consists of a figure wearing a himation (probably the father), a

architecture in Rhodes in the Hellenistic age: local documentation and forms of contact"], Bollettino di Archeologia on line, vol. speciale C/C7/4(2010): 51, figs. 10-11; O. Palagia, "Commemorating the Dead: Grave Markers, Tombs, and Tomb Paintings, 400-30 BCE", 2016, 376, fig. 26.1; W. Childs, Greek Art and Aesthetics in the Fourth Century B.C. (Princeton: Princeton University Press, 2018), 224-225, fig. 247.

12. See O. Palagia, "Commemorating the Dead: Grave Markers, Tombs, and Tomb Paintings, 400-30 BCE", 2016, 376. 
shorter naked athlete (perhaps the son), and another even shorter nude figure with a mantle on his shoulder (the servant carrying his master's clothes). Although other fragments attest to the existence of similar monumental structures in Attica, the Kallithea Monuments is the only building that has survived almost entirely, thus providing concrete evidence for comparison with other similar structures built in other places, such as in South Italy.

\section{Tarantine Funerary Naiskoi and their Sculpture}

Thousands of architectural fragments and sculpture from the mid-fourth to the mid-second centuries $\mathrm{BC}$ have been found to date in the necropolis of Taranto. ${ }^{13}$ Also, numerous representations of naiskoi on large Apulian redfigure vases attest to their existence. ${ }^{14}$ The pottery contexts largely consisting of red-figure, Gnathia, and black glazed wares, as well as unguentaria, indicate that these funerary structures were common in the period $325-250 \mathrm{BC}^{15}$

The Tarantine version of these small-scale structures is usually built in local limestone and feature columns of the local Tarantine-Corinthian order (Figure 2). ${ }^{16}$ Sometimes, they were large enough to house statues similar to the funerary naiskoi shown in Apulian vase-painting of the last quarter of the fourth century BC. They were erected above the chamber tombs of the local aristocracy and were embellished with sculptural friezes, metopes, pedimental relief figures, and, in some cases, acroteria. ${ }^{17}$ The best preserved example is the naiskos found in 1959 on Via Umbria, Chamber Tomb I. Carter reconstructed its architectural features and sculptural programme in 1970 (Figure 3). It is today displayed in the archaeological museum of Taranto, but with the metopes placed around the podium instead of the architrave. ${ }^{18}$

13. See study edited by E. Lippolis, Taranto la necropolis: Aspetti e problem della documenbtazione archeological tra VII e I a.C. Catalogo del Museo Nazionale Archeologico di Taranto, III.1 (Taranto: La Colomba, 1994).

14. O. Palagia, "Commemorating the Dead: Grave Markers, Tombs, and Tomb Paintings, 400-30 BCE", 2016, 380. For Tarantine naiskoi, see H. Klumbach, Tarentiner Grabkunst (Reutlingen, 1937); J.C. Carter, "Relief Sculptures from the Necropolis of Taranto". AJA 74, no. 2(1970): 125-126; J.C. Carter, The Sculpture of Taras, Transactions of the American Philosophical Society 65, no. 7 (Philadelphia, 1975), 15-16. E. Lippolis, "La tipologia dei semata", in Taranto la necropoli: Aspetti e problem della documentazione archeologica tra VII e I sec. a. C. Catalogo del Museo Nazionale Archeologico di Taranto III.1, 1994, and "Vaste, Ipogeo delle Cariatidi: sculture architettonica del vestibolo", in Vecchie scavi, nuovi restauratori. Catalogo della Mostra di Taranto, ed. E. Lippolis (Taranto: Scorpione, 1991); E. De Juliis, Taranto (Bari: Edipuglia, 2000), 65; E. Lippolis, "Tipologie e significati del monumento funerario nella cità ellenistica. Lo sviluppo del naiskos", 2007.

15. See J.C. Carter, The Sculpture of Taras, 1975, 22-23, tab. 1 and 2.

16. J.C. Carter, The Sculpture of Taras, 1975, 16; E. Lippolis, "Vaste, Ipogeo delle Cariatidi: sculture architettonica del vestibolo", 2007, 100.

17. E. Lippolis, "La tipologia dei semata", 1994, 109-128.

18. For J.C. Carter's reasons in support of his model, see Relief Sculptures from the Necropolis of Taranto, 1970, 130, fig. 32. 


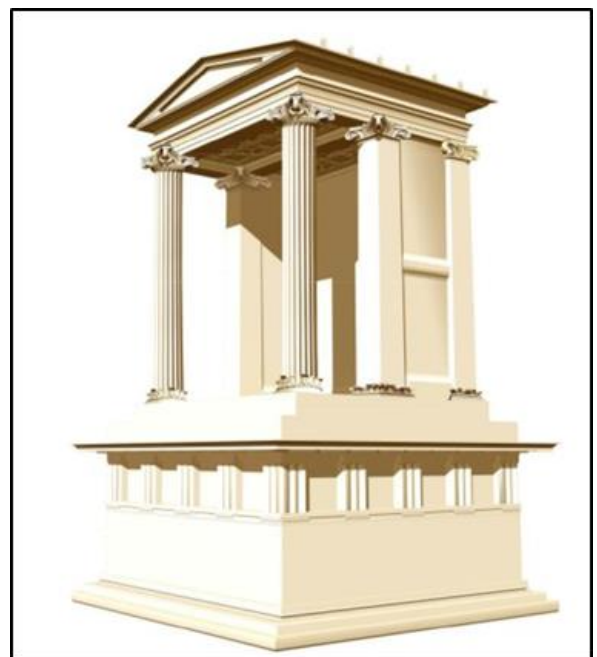

Figure 2. Taranto, naiskos found on Via Umbria Source: R. Belli Pasqua, 2010, fig. 13.

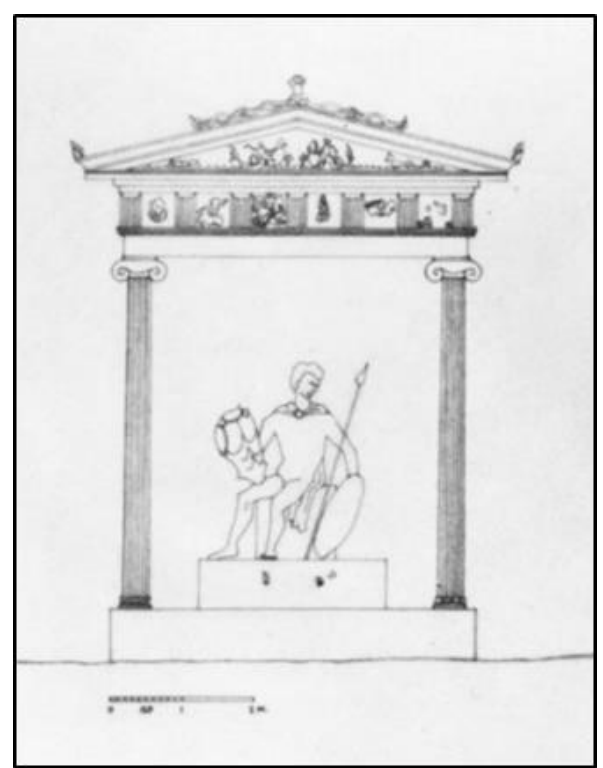

Figure 3. Taranto, naiskos found on Via Umbria

Source: adapted from J.C. Carter, 1970, AJA 74(2): 125-137, fig. 32.

The chronology of Tarantine funerary sculpture is based entirely on stylistic Greek developments and from Athenian temple and grave reliefs in particular. It was first studied by Lenormant, who was followed a few decades later by Pagenstecher and Caianello. ${ }^{19}$ It was not until 1937 when Klumbach published the first comprehensive stylistic analysis of the subject, an approach also taken by Bernabò-Brea in the 1950s. Two decades later, Carter made a

19. F. Lenormant, Gazzette Archéologique (Paris: Lévi, 1881-82), 172-173; R. Pagenstecher, Unteritalische Grebdenkmäler [Underground grave monuments] (Strassburg, 1912); M. Caianello, "Studi sull'arte tarantina" ["Studies on Tarantine art"] Museion I (1923): 58-63, 126130. For the context of Tarantine sculpture within Magna Graecia, see C. Picón, "Sculptural Styles of Magna Graecia", in Magna Graecia: Greek Art from South Italy and Sicily. The Cleveland Museum of Art, ed. M. Bennett, A. Paul and M. Iozzo (New York and Manchester: Hudson Hills, 2002), 68-81. 
more modern approach that considered the contextual situation of the findings. His work on the funerary sculptures from Taranto is exhaustive, but a number of scholars have questioned some of his stylistic attributions and conclusions. ${ }^{20}$ For example, in his analysis of all the materials found in the necropolis, Lippolis considers the architectonic contexts of the findings as well and studies them in connection with their typological and chronological developments, providing a more reliable typology and chronology of the monuments. Among these, he identifies different types of semata, such as stelai, columns, stone vases, cistae, altars, louterion, and trapeze as well as naiskoi of the mausoleum, tower, and tholos types. ${ }^{21}$

The figured decoration is also varied, with Dionysian and marine thiasosscenes, Amazonomachies, Centauromachies, vegetal and animal friezes, as well as battle, rape, and Underworld scenes. The period between 330 and $300 \mathrm{BC}$ shows a new production of funerary monuments in local limestone, reducing material and labour costs that are ultimately reflected in an increase of funerary exemplars. More expressive figures and new stylistic features, such as more dynamic himatia materialise in the thiasos scenes on friezes, in the various acroteria, and in rape and Amazonomachy scenes.

Most of the extant relief sculptures featuring Amazonomachies from Taranto were found in the first decades of the twentieth century in a very fragmented state. Some of them have known provenance (mostly from the Arsenale area), while other pieces came from the Rocca collection. ${ }^{22}$ Although more fragmented than the Attic examples, it is still possible to classify the Tarantine sculptures as part of pediments (MARTA inv. no. 7, and 9-10; C92), metopes (MARTA inv. no. 71, 193, and 212), reliefs (Budapest no inv. no., MARTA inv. no. 16, 148, 17097, 17104; C39; C88, C89, C96, C399), almost in-the-round figures (MARTA inv. no. 91, 92, 135, 17111; C8). There are also acroteria (MARTA inv. no. 140-142) and one appliqué (MARTA inv. no. 100). ${ }^{23}$ In total, there are thirty-nine sculptural fragments featuring scenes of the Amazonomachy, alongside other additional eighteen pieces, largely fragmented, that most likely represent the same subject. This study will analyse only those better preserved, thus allowing a more reliable iconographic comparative material. These include the relief fragment in Budapest (C56), the frieze depicting an Amazonomachy with Heracles (C88), a carved metope

20. J.C. Carter's chronology has been questioned by E. Lippolis, "La necropoli ellenistica: problemi di classificazione e cronologia dei materiali" ["The Hellenistic necropolis: problems of classification and chronology of the materials"], in Taranto la necropoli: Aspetti e problem della documentazione archeologica tra VII e I sec. a. C. Catalogo del Museo Nazionale Archeologico di Taranto III.1, 1994, 238-281. O. Palagia, "Joseph Coleman Carter: The Sculpture of Taras", The Classical Review 28(1), 1978, 189, has also questioned some of his stylistic classifications. These contentions, however, do not undermine J.C. Carter's remarkable study.

21. E. Lippolis, "La tipologia dei semata", 1994, 108-129.

22. For the thiasos area of Taranto's necropolis, see E. De Juliis, Taranto, 2000, 68, n. 35.

23. When known, L. Bernabò-Brea, "I relieve tarantini in pietra tenera" ["Tarantine reliefs in limestone"], RivIstArch 1 (1952), provides precise information about the find spots of the sculptures. See also J.C. Carter, The Sculpture of Taras, 1975, 14, n. 39.

23. From now on, "C" stands for the entry in J.C. Carter's 1975 catalogue, and MARTA for Museo Archaeologico di Taranto. 
(C50), and three examples of pedimental sculptures (MARTA inv. 7, 9, 10, and C92).

\section{Methods: Archaeological Contexts and Iconography}

Before discussing the monuments, a few words on our methodological approach are needed. Indeed, it is worth looking at the archaeological contexts of naiskoi with their iconography, since bringing related materials to the discussion highlights the extent to which our monuments are similar to or different from other contemporary funerary monuments.

Context and its problems have been a debated topic in archaeology during recent decades. However, in the archaeological study of myth, context is often neglected. ${ }^{24}$ In this respect, it is crucial to bear in mind that in the particular context of funerary monuments the images displayed on them were part of a whole burial assemblage; by being removed from it, they are almost meaningless. Therefore, it is mandatory to think of the Amazonomachies as one piece within a larger funerary structure that may feature other subjects as well. Moreover, the mingling of diverse architectonic and sculptural techniques to create an original and unique monument indicates that there was an intended meaning that viewers at the time would have acknowledged.

The adaptation of Greek and eastern funerary models as well as the cultural reception of heroic myth in general, and the Amazonomachy, in particular, are thus a central preoccupation in this line of inquiry.Thereby, it is worth asking about the need to import visual languages to different geographic contexts. In this respect, Miller's account of how Persian material culture and art exerted influence in Attica has successfully demonstrated the benefits of this approach, distinguishing between imitations, adaptation, and derivation. ${ }^{25}$ The latter concept becomes relevant since our monuments present stylistic derivation from the East in the case of the Kallithea Monument in Athens, and from Attica with its eastern overtones in the case of Taranto.

An iconographic analysis of the monuments reveals some critical features. In the first place, the imagery on the Kallithea Monument shows not only its correspondence with Greek developments but also a marked eastern flavour. The Amazonomachy shows two types of warriors on the existing slabs: some are nude and wear only helmets, one wears a cuirass. The Amazons' weapons, perhaps quivers or spears, were added in paint that is no longer visible. They fight on foot except for one on horseback. The fact that the composition is arranged into duels with no overlapping figures has led some scholars to think that the frieze sculptors were following standard "design books" (Figure 4). ${ }^{26}$ Similarly, the frieze of animals with its lion griffin

24. T. Hölscher "Myth, images and the typology of identity in Greek art", in Cultural Identity in the Ancient Mediterranean, ed. E. Gruen (Los Angeles, 2011); K. Junker Interpreting the Images of Greek Myths: An Introduction (Cambridge: Cambridge University Press, 2011), 105.

25. M. Miller, Athens and Persia in the Fifth Century BC: A study in cultural receptivity (Cambridge: Cambridge University Press, 1997), 137-149.

26. B.S. Ridgway, Hellenistic Sculpture I, 331-200 BC, 1990, 32. 
suggests derivation from the East, perhaps Lycia and Caria, where such friezes were common in funerary art. ${ }^{27}$ In addition, the funerary statues against their naiskos background must have evoked the Daochos Monument at Delphi, a roughly contemporary sculptural monument. In short, the total effect of the monument is more eastern than Attic. ${ }^{28}$

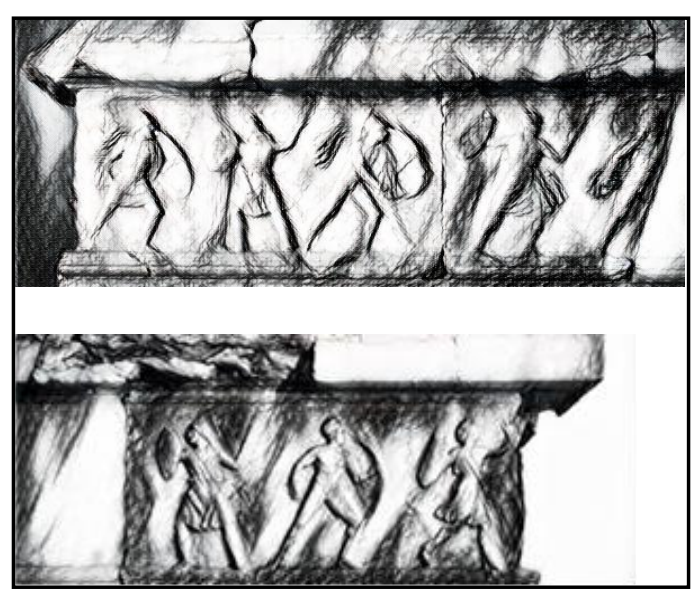

Figure 4. Piraeus Museum, Kallithea Monument. Amazonomachy Source: sketches by the author from the original.

Although very fragmented, other slabs from Attic funerary monuments featuring Amazonomachies have come to us. Slab NM 3614, also from Kallithea, must have come from a building very similar to the Kallithea Monument. ${ }^{29}$ Another from the Kerameikos ( $c$. $30 \mathrm{~cm}$ high) has survived in

27. On derivation, see M. Miller, Athens and Persia in the Fifth Century BC: A study in cultural receptivity, 1997, 147-150; (in the Kallithea Monument) A. Hagemajer, "Becoming the 'Other': Attitudes and Practices at Attic Cemeteries", in The Cultures within Ancient Greek Culture: Contact, Conflict, Collaboration, ed. C. Dougherty and L. Kurke (Cambridge: Cambridge University Press, 2003), 207-236, esp. 210-212.

28. B.S. Ridgway, Hellenistic Sculpture I, 331-200 BC, 1990, 32. On the Daochos Monument, see T. Dohrn, "Die marmor Standbilder des Daochos Weihgeschenks in Delphi" ["The marble statues of Daochos' votive offerings at Delphi"]. AntP: 33-53(1968), 33-53; A. Stewart, Greek Sculpture: An Exploration (New Haven \& London: Yale University Press, 1990), 187; C. Edwards, "Lysippos", in Personal Styles in Greek Sculpture. Yale Classical Studies 30, ed. O. Palagia and J. Pollitt (Cambridge and New York: Cambridge University Press, 1996), 136-137; W. Geominy, "The Daochos Monument at Delphi. The Style and Setting of a Family Portrait in Historic Dress", in Early Hellenistic Portraiture. Image, Style, Context, ed. P. Schultz and R. von den Hoff (Cambridge: Cambridge University Press, 2007), 84-98. More recently, E. Aston, "Thessaly and Macedon at Delphi", in The Greek World in the 4th and 3rd Centuries B.C. (Electrum 19), ed. E. Drabowa (Krakow: Jagiellonian University Press, 2012), 41-60, esp. 45-48; W. Childs, Greek Art and Aesthetics in the Fourth Century B.C., 2018, 225, fig. 132.

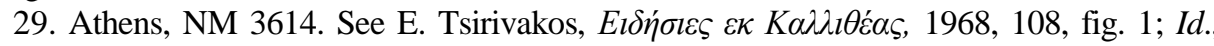
Kallithea: Ergebnisse der Ausgrabung, 1971, 110; W. Schiering, "Zum Amazonenfries des Maussoleums in Halikarnass" ["On the Amazons' Frieze from the Mausoleum at Halikarnassos"], JdI 90 (1975): 132-133, fig. 6; LIMC 1, s.v. Amazones, no. 429 (note the relief is attributed to the Kallithea Monument); N. Kaltsas, Sculpture in the National Archaeological Museum, Athens, 2002, 351, fig. 531; E. Lippolis, "Vaste, Ipogeo delle Cariatidi: sculture architettonica del vestibolo", 2007, 92; W. Childs, Greek Art and Aesthetics in the Fourth Century B.C., 2018, 225, fig. 248. 
eight fragments depicting seven combating figures and one arm in a long sleeve, thereby suggesting that the subject might be an Amazonomachy. ${ }^{30}$

Tarantine sculptures set in funerary structures were usually carved in a soft and white limestone, constituting a distinctive group dating from the late fourth to the first half of the third century $\mathrm{BC} .^{31}$ The evidence includes small acroterial sculptures in-the-round and relief sculptures that were often placed in the entablature, including figured friezes, metopes, pediments, and sometimes, caryatids. ${ }^{32}$ Most Tarantine reliefs are quite small in scale, rarely surpassing a height of $20 \mathrm{~cm}$. They feature different styles and degrees of quality, yet the best examples show that local sculptors were well aware of the mainstream sculptural trends in Attica and other regions of the Greek world. ${ }^{33}$ Moreover, some examples even anticipate baroque trends usually associated with later Hellenistic works, perhaps inspired in contemporary painting, as we shall see.

\section{Findings}

In examining the extant material from these different geographic areas, some observations came to light. First, the Amazonomachy frieze on the Kallithea Monument is unusual in a funerary structure that does not seem to commemorate an individual with such attributes. Different from contemporary examples in other places in the Mediterranean that usually honour dynasts and warriors, the three statues in the monument - citizen, athlete, and slave - highlight the high social status of the deceased individual, but it tells us nothing about his deeds. In opposition, the example from Taranto found on Via Umbria only features battle scenes; thereby we can only presume about how the Amazonomachies in their original setting were linked to the occupants in the tomb.

Second, the architectonic structures of Attica and Taranto alongside their decoration mingle local iconography with foreign artistic trends. In Attic grave reliefs, for example, statues of auxiliary figures such as slaves, archers, or sirens are commonly seen in local funerary precincts throughout the fourth century BC. ${ }^{34}$ The Kallithea Monument, for example, not only echoes the iconography of Athenian grave reliefs but also emulates the dynastic burials

30. U. Knigge, "Marmorakroter und Fries von einem attischen Grabbau?" ["Marble acroterium and frieze from an Attic funerary building?"] AthMitt 99(1984): 217-234.

31. J.C. Carter, The Sculpture of Taras, 1975, 14; C. Picón, "Sculptural Styles of Magna Graecia", in Magna Graecia: Greek art from South Italy and Sicily, ed. M. Bennett, A. Paul and M. Iozzo. The Cleveland Museum of Art (New York and Manchester: Hudson Hills, 2002), 78.

32. For example, in the Hypogeum of the Caryatids from Vaste. See E. Lippolis, "Vaste, Ipogeo delle Cariatidi: sculture architettonica del vestibolo", 2007, 149-158. For the findings, see E. Lippolis, Arte e artigianato in Magna Grecia, 1996, with bibliography; E. De Juliis, Taranto, 2000, 114-115.

33. See R. Belli Pasqua, Taranto: la scultura in marmo e in pietra. Catalogo del Museo Archaeologico Nazionale di Taranto. IV. 1 (Taranto: La Colomba, 1995), 1-8.

34. For funerary statues of the fourth century BC, see A. Scholl, "Der Perser und die skythischen Bogenschützen zu dem Kerameikos" ["The Persian and the Skythian archers in the Kerameikos"]. JDAI 115(2001): 79-112 (with bibliography). 
of Lycia and Caria. ${ }^{35}$ The Tarantine examples not only took on these trends, but they also show original architectonic features, such as placing the metopes in the podium instead of the entablature and introducing the so-called Corinthian-Tarantine capital. Besides, the extant examples show an interest not only in the Amazonomachy but also in a wider variety of myths than those observed in Attic funerary monuments.

Third, the Kallithea Monument predates similar monuments in other Greek cities outside Attica, setting a precedent for the Tarantine production. After Demetrios of Phaleron's decree, it is not clear what happened to Athenian workshops, but it is likely that artists immigrated to other Greek centres, including Rhodes and Taranto. While closer models to those made in Athens are found in naiskoi from Rhodes, which follow the Attic architectonic trend with Ionic capitals (Figure 5), Taranto offers the most compelling evidence for late Classical and Hellenistic funerary monuments. ${ }^{36}$

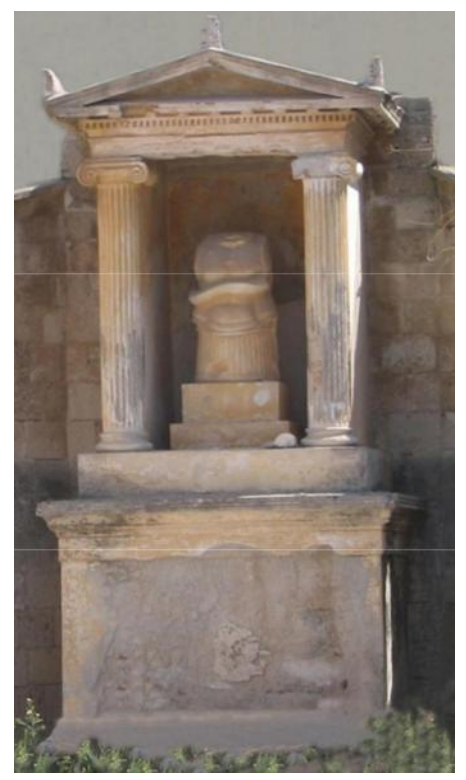

Figure 5. Rhodes, Archaeological Museum. Funerary Naiskos Source: R. Belli Pasqua, 2010, fig. 6.

Fourth, in the case of the Tarantine sculptural developments, it is essential to evaluate the extent to which other media might have contributed to their production. In this respect, the role of terra-cotta models and to a more significant extent, painting, needs to be taken into consideration. ${ }^{37} \mathrm{I}$ am here concerned with the latter as it seems that painted models made by local artists inspired more dynamic developments in sculpture.

Finally, except for the fragments from the Kerameikos, scenes of myth on Attic funerary monuments come from a peripheral area. Regardless of

35. O. Palagia, Commemorating the Dead: Grave Markers, Tombs, and Tomb Paintings, 400-30 BCE, 2016, 376.

36. For a comparative study on Rhodian funerary architecture, see R. Belli Pasqua, "Architettura funeraria a Rodi in età ellenistica: documentazione locale e forme di contatto", 2010, 43-57.

37. For the role of other crafts, see J.C. Carter, The Sculpture of Taras, 1975, 26-29. 
how subtle allusions to myth occur in Athenian tombstones, they are never as explicit as in the examples from Kallithea where they were set far from the city. This final point is important since in considering the Amazonomachy in the funerary contexts from Attica and Taranto, it seems evident that the subject was treated in different ways. This dissimilarity is given not only because Amazons were placed in different spots of the funerary structures, but also because they seem to differ both in their iconography and intended meaning. This issue forms the focus of the following discussion.

\section{Discussion}

Exotic combats such as the Amazonomachy seem to have acquired a definite funerary connotation of their own by the late fourth century BC. Some have explained the flourish of the subject during this period as a reflection of the fame of the Mausoleum at Halikarnassos and other Lycian monuments. ${ }^{38}$ These colossal monuments were built not only in a larger scale but also featured lavish decoration, including heroic battles and Amazonomachies, among other myths. Furthermore, in Etruscan funerary art, the Amazonomachy frequently appears on both painted and carved sarcophagi, while the Amazon Sarcophagus in Vienna provides a further example from, probably, Cyprus. ${ }^{39}$ In their own particular way, each of these funerary monuments was unique in attempting to convey heroic overtones to the deceased individual. In this context, the Amazonomachy seems to have been a preferred subject by both dynasts and members of the local elites in different parts of the Mediterranean.

As in many other monuments of the Classical period, there emerges a tale of civilised Greeks defeating "otherness", namely savage fighting women from the East as a reference to the Athenian victory over the Persians. This subject set in the Parthenon and other public monuments became iconical. However, can we assume that the same meaning was to be grasped by the

38. L. Bernabò-Brea, I relieve tarantini in pietra tenera, 1952, 115. For the sculpture of the Lycian tombs and the Mausoleum see I. Jenkins, Greek Architecture and Its Sculpture (London: The British Museum Press, 2006), 151-185 and 203-235 respectively. Also, K. Jeppensen, "The Mausoleum at Halicarnassus: Sculptural decoration and architectural background", in Sculptors and Sculpture of Caria and the Dodecanese, ed. I. Jenkins and G. Waywell (London: The British Museum Press, 1997).

39. L.B. van der Meer, Myths and More: On Etruscan Stone Sarcophagi (c. 350- c. 200 B.C.) (Louvain: Dudley, 2004), 32-36; A. Bottini and E. Setari, Il Sarcofago delle Amazzoni [The Amazons' Sarcophagus] (Milan: Electa, 2007); V. Riedemann Lorca, Greek Myths Abroad: A Comparative Regional Study of Their Funerary Uses in Apulia and Etruria (DPhil Dissertation, University of Oxford, 2016), 142-154. For the Amazon Sarcophagus in Vienna, see J. Ferron, "Le sarcophage des Amazones" ["Amazons' sarcophagus"], in Sarcophages de Phénicie: Sarcophages a scènes en Relief (Paris: Librarie orientaliste Paul Geuthner, 1993) and monograph by R. Fleischer, "Der Wiener Amazonensarkophag" ["The Amazons' Sarcophagus in Vienna"]. Antike Plastik 26(1998) (with discussion on chronology on pages 36 and 5); LIMC, Amazones, no. 435. The monument is said to be from Cyprus (?) and is attributed to the school of Lysippus at the end of the fourth century BC. See also B.S. Ridgway, Hellenistic Sculpture I, 331-200 BC, 1990, 45-46. 
spectators of our monuments more than a century later? If not, then what would be the cultural implications of the Amazonomachy when placed in the funerary temple-like structures from Attica and Taranto?

\section{Amazons in Attic Naiskoi}

Attic and Tarantine naiskoi were smaller structures and featured moderate decorative programmes in comparison to their eastern counterparts, but for all that, they were still significant structures in their local communities. The Amazonomachy in the Kallithea Monument and the one depicted on slab NM 3614 share a similar design, with the figures arranged in duels and placed within a reasonable space between them. In what is left of the frontal frieze of the Kallithea Monument, both Amazons and Greeks fight on foot, while one Amazon is on horseback in the slab around the right corner, recalling a similar motif observed on one of the Parthenon's West metopes (Figure 7). The frieze shows a duel between a Greek and an Amazon, followed by another Amazon who was probably facing a Greek (now lost). The scene on the surviving slab to the right is interesting since it shows a flying Amazon who is being chased by a Greek (Figure 4, right). She looks backwards while she is running away as if asking for help, being the most original composition in what is otherwise a monotonous frieze.

By contrast, the Amazonomachy depicted on slab NM 3614, is more dynamic (Figure 6). The remaining figures show an Amazon fighting a Greek, and another Amazon engaged in battle with another Greek, now missing. The dense drapery and flying mantles add more dynamism to the scene, which depicts the Amazons in the oriental fashion with trousers and sleeves. In addition, the surviving arm in a long sleeve on one of the fragments from the Kerameikos mentioned aboved suggests that representing Amazons as distinctly oriental -something widely observed in vase painting, but no so often in public buildings- was perhaps a more extended trend in funerary sculpture. Unfortunately, no remains are indicating the main hero, thus making impossible to identify the specific Amazonomachy intended for this funerary building. ${ }^{40}$

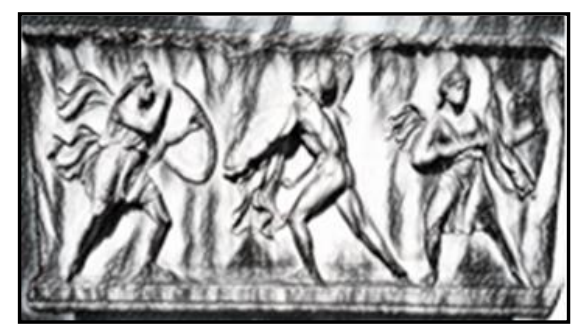

Figure 6. Athens, NM 3614. Amazonomachy

Source: sketch by the author from the original.

40. Note that several Amazonomachies depicted on Etruscan sarcophagi show no main hero in contrast to the Amazonomachies on eastern funerary monuments (usually Heracles). However, anonymous Amazonomachies seem to be an unlikely choice for the Attic examples. 


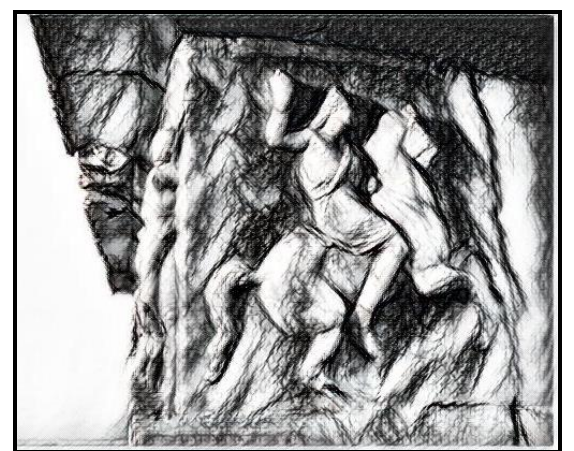

Figure 7. Piraeus Museum, Kallithea Monument. Amazon on Horseback Source: sketch by the author from the original.

In looking at these reliefs and in trying to place them back into their original contexts, the modern viewer wonders about the visual impact and symbolism they may have had in antiquity. In the case of the Kallithea Monument, it is likely that a funerary structure of such characteristics was endured as a private memorial only because it was far from the city cemeteries. $^{41}$

That said, the Attic examples are to some extent just a reflection of their eastern counterparts. With their schematic arrangement and reduced dynamism, the Amazonomachies portrayed in these Attic monuments seem to be stripped of their original meaning. Instead, their function seems to be reduced to furnishing the funerary building with some exotic overtones. In any case, it is important to point out that the iconography of Attic funerary tombstones shows that, in some cases, myths might appear to invest particular individuals with heroic attributes. This particularity is observed, for example, on the exacerbated muscles and pose of the nude male figure that resembles some of Heracles' attributes in the Illisos Stele. ${ }^{42}$ Apart from that, heroic postures and combat scenes are more common as, for instance, in the funerary naiskos of Aristonautes and the Daxileos' Stele (about 320 BC). ${ }^{43}$ These monuments symbolise the shift of emphasis from Attic models to the non-Greek world of Asia Minor, before Alexander's great expansion to the East. Thereby, the introduction of the Amazonomachy must have followed a similar trend.

\section{Amazons in Tarantine Naiskoi}

Turning to the development of the Tarantine sculptural production, this shortly reached its own expressive language featuring rich and original decorative programmes, including a more extensive variety of episodes of myth than those observed in Attic funerary art. As mentioned before, Amazons,

41. See J. Boardman, Greek Sculpture: The Late Classical Period, 1995, 117.

42. See the excellent study on afterlife images on Attic funerary monuments of the Classical period by A. Scholl, "Hades and Elyseon - images of the afterlife in Classical Athens", in Exploring Ancient Sculpture: Essays in Honour of Geoffrey Waywell, ed. F. Macfarlane and C. Morgan (London: Institute of Classical Studies, 2010), 71-96.

43. Kerameikos Museum P 1130. J. Boardman, Greek Sculpture: The Late Classical Period, 1995, fig. 120; B.S. Ridgway, Fourth-Century Styles in Greek Sculpture (Madison: The University of Wisconsin Press, 1997), 3-7, fig. 1, pl. 1. 
rape and thiasos-scenes are common. Another very fine relief fragment from a funerary monument shows Electra and Orestes at the tomb of Agamemnon, a scene also depicted on a red-figure bell-krater by the Sarpedon Painter (400380 BC), also from Taranto. ${ }^{44}$ The inclination of heads and sorrowful expressions clearly derive form Athenian grave reliefs. Consequently, the funerary iconography of Taranto seems to follow the stylistic trends from the Greek mainland but transposes it to the realm of myth.

To reconstruct the original setting and the symbolism of the Amazonomachy in Tarantine naiskoi two aspects deserve special consideration: one has to do with the placement of these reliefs in the buildings, and the other with considering some similar iconography provided by other contemporary media, such as vase and tomb painting.

About six hundred vases with depictions of naiskoi have come to us. ${ }^{45}$ They attest to the existence of actual funerary buildings with triglyph and figured metope friezes depicted around the podium, but they never show evidence for the relief friezes or pedimental sculptures found in the necropolis of Taranto. ${ }^{46}$ In fact, the evidence for naiskoi that have been found up to the present dates from the last decades of the fourth century BC, whereas their depiction on Apulian vases is already visible in works by the Ilioupersis Painter, who was active between 370 and 340 BC. Hence, this represents a production that is posterior to the examples depicted on the vases. This evidence is further confirmed by the fact that painted naiskoi usually show Ionic capitals, while the actual Tarantine ones show a type of local version of the Corinthian capital. ${ }^{47}$ In spite of that, naiskoi depicted on Apulian vases show that there was a correlation with actual ones. For instance, they simulate the marble or texture of the stone while the figures depicted inside are usually painted in white (the figures bringing offerings around the naiskos are usually coloured in the red-figure technique), as observed on a volute krater in London. ${ }^{48}$ In fact, large parts of marble statues have been found in tombs of Taranto, hence suggesting that these belonged to statues of the heroised dead depicted inside the naiskoi. ${ }^{49}$ Furthermore, two Apulian red-figure loutrophoroi by the Metope Group (350-340 BC) depict a naiskos-

44. New York, MET 05089. Limestone relief from Taranto, ca. 300 BC. For the vase, see RVAp I 164, 3; LIMC, Elektra I, no. 35; E. Lippolis, "La tipologia dei semata", 1994, 40, fig. $19 \mathrm{a}$.

45. E. De Juliis, Taranto, 2000, 114. See also Pontrandolfo et al., "Semata e naiskoi nella ceramica italota" ["Semata and naiskoi on Italote ceramics"]. AION 10(1988): 181-202.

46. For naiskoi on vases from Taranto and other Italic sites, see L. Todisco, "Vasi con naiskoi tra Taranto e centri italici" ["Vases with naiskoi between Taranto and Italic centres"], in Inszenierung von Identitäten: Unteritalische Vasenmalerei zwischen Griechen und Indigenen, ed. U. Kästner and S. Schmidt (Munich: Verlag der Bayerischen Akademie der Wissenschaften, 2018), 99-107.

47. J. C. Carter, The Sculpture of Taras, 1975; E. De Juliis, Taranto, 2000, 126.

48. London, BM 1849, 0518.4 (F 283). RVAp 8/7; M. Denoyelle and M. Iozzo, La Céramique Greque d'Italie méridionale et de Sicile: Productions colonials et apparentées du VIIIle au III av. J.-C [The Greek pottery of southern Italy and Sicily: Colonial and related productions from the 8th to the 3rd BC. J.-C] (Paris: Picard, 2009), 139, fig. 199, pl. 17.

49. See J.C. Carter, Relief Sculptures from the Necropolis of Taranto, 1970, 131, n. 22. 
scene with a woman and a servant inside. ${ }^{50}$ These exemplars are not different from other similar scenes apart from the fact that single Amazons are depicted on the metopes around the podium (Figure 8). Could these representations find a correlation with actual funerary naiskoi in the region?

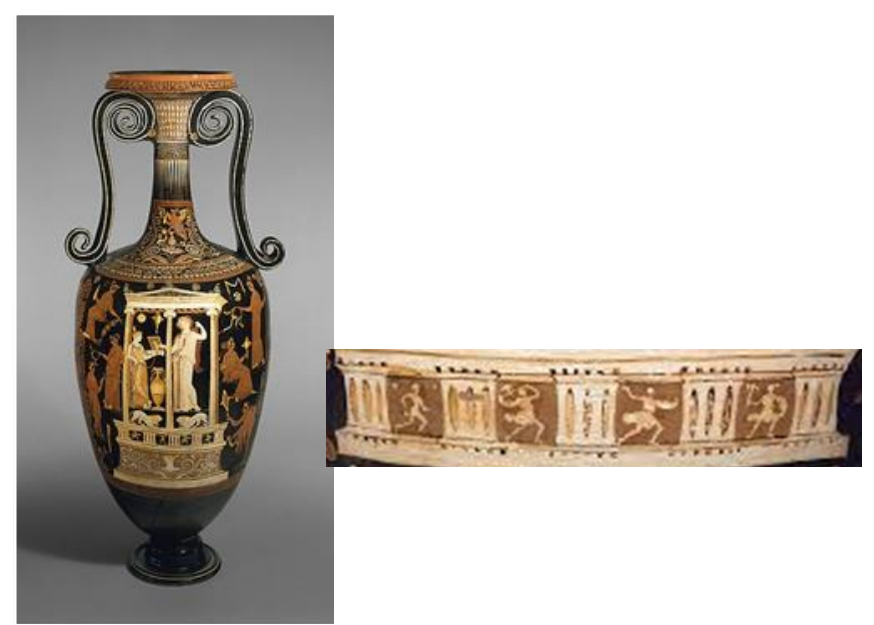

Figure 8. New York, MET inv. 1995.45.1 and 1995.45.2 (detail). Apulian redfigure loutrophoroi by the Metope Painter

Source: MET open access images.

These difficulties could be solved if we give Apulian vase painting some predominance over Tarantine funerary architecture, assuming an influence of the former over the latter. If this is the case, we may presuppose that Apulian vase-painters were inspired by Athenian monuments which date to an earlier date than the Tarantine ones. Another possibility is that local artists made graphic elaborations of these monuments, eventually representing them more complex and richly decorated. ${ }^{51}$ In any case, it is not irrelevant to point out that naiskos-scenes depicted on vases come almost entirely from Apulia with a few exceptions from Lucania. Campanian, Paestan, and Sicilian vases depicting such scenes have not been found yet, hence suggesting the existence of a funerary iconography specific to Taranto and the Apulian region, concentrating in Monte Sannace, Ceglie and, for the most part, Ruvo.

Regardless of how we consider this dilemma, there is yet another aspect that requires attention: the high probability that other kinds of painted monuments existed in Taranto at the time that could be stylistically and thematically related to the iconography of the naiskoi. Different from Etruria from where we have numerous examples of fourth-century BC tomb painting, the evidence from South Italy is limited. Since the extant painted tombs at Taranto do not feature narrative scenes, we have to look once more at the Italic centres from where we have some evidence.

50. New York, Metropolitan Museum of Art, inv. 1995.45.1, 2. RVAp Supp. I 72, no. 18/16e, pl. X, 4; A.D. Trendall, The Red Figure Vases of South Italy and Sicily (London: Thames \& Hudson, 1989), 85, no. 181; M. Denoyelle and M. Iozzo, La Céramique Greque d'Italie méridionale et de Sicile: Productions colonials et apparentées du VIIIe au III av. J.-C, 2009, 17, pl. 18.

51. See E. De Juliis, Taranto, 2000, 126. 
The paintings in the Tomb of the Dancers from Ruvo dated to the first half of the fourth century $\mathrm{BC}$, for example, are remarkable in the dynamism given to the drapery of the dancing female figures and the painter's colourful "palette". ${ }^{52}$ Another example is the Tomb of the Cerberus in Canosa (late fourth-early third century $\mathrm{BC}$ ), which shows a scene of passage to the Underworld placed above the entrance of one of the tomb's chambers, resembling very much to a continuous frieze. ${ }^{53}$ Based on this evidence, it is thus possible to assume that similar tomb paintings could have been part of the funerary repertoire at Taranto during this period as well and thus closer to Macedonian practices. ${ }^{54}$

There is, nonetheless, a final example that is more closely connected with this study not only because of its exceptionality, but also because it is a painted funerary monument featuring an Amazonomachy: the so-called Sarcophagus of the Amazons in Florence (350-325 BC) ${ }^{55}$ Made of alabaster for a member of the Etruscan elite at Tarquinia, the paintings on the sarcophagus were for a long time thought to have been of Etruscan manufacture. However, a study by Brecoulaki has demonstrated that the paintings were the product of a South Italian workshop, perhaps located in Taranto. ${ }^{56}$ This funerary monument indicates that the Amazonomachy as a funerary subject enjoyed an assured status among different peoples in ancient Italy, including among the Tarantine Greeks.

Some of the motifs painted on the Sarcophagus of the Amazons find a correlation with the surviving sculptural fragments from the necropolis of Taranto. For example, on one of the long sides of the sarcophagus, a kneeling Amazon holding her pelta is portrayed in the act of clutching her sword

52. Naples, MAN inv. 9357. See G. Gadaleta, La Tomba delle Danzatrici di Ruvo di Puglia [The Tomb of the Dancers from Ruvo di Puglia]. Quaderni di Ostraka 6 (Loffredo, 2002); L. Todisco, "La tomba delle Danzatrici di Ruvo" ["The Tomb of the Dancers from Ruvo"], in Mitti Greci dalla Magna Graecia al collezionismo, ed. G. Sena Chiesa (Milano: Electa, 2005 2005).

53. E. De Juliis, "Ipogeo del Cerbero" ["The Hypogeum of Cerberus"], in Principi Imperatori Vescovi: Duemilaanni di historia a Canosa, ed. R. Cassano (Bari: Marislio, 1992), 348-349; M. Mazzei, Arpi: L'ipogeo della Medusa e la necropolis [Arpi: The hypogeum of the Medusa and the necropolis] (Bari: Edipuglia, 1995), 206; S. Steingräber, "La pittura funeraria della Daunia: elementi iconografici caratteristici nel contesto della pittura apula, magnogreca a miditerranea preromana (IV-III a.C.)" ["The funerary painting from Daunia: characteristic iconographic elements in the context of Apulian, Magnogrecan and Mediterranean pre-Roman painting (IV-III a.C.)"], in Storia e Archeologia della Daunia: Atti delle Giornate di studio (Foggia 19-21 maggio 2005), ed. G. Volpe, M. Strazzulla and D. Leone (Bari: Edipuglia, 2008), 191.

54. See S. Steingräber, Arpi-Apulien-Makedonien. Studien zum unteritalischen Grabwesen in hellenistischer Zeit [Arpi-Apulia Macedonia. Studies on south Italian tomb structures in Hellenistic times]. Mainz: Phillip von Zabern, 2000.

55. Florence, MAN, inv. 5811, from Tarquinia, Monterozzi Necropolis (1869). L.B. van der Meer, Myths and More: On Etruscan Stone Sarcophagi (c. 350- c. 200 B.C.), 2004, 35-36, fig. 12-13; A. Bottini and E. Setari, Il Sarcofago delle Amazzoni, 2007.

56. H. Brecoulaki, L'esperienza del colore nella pittura funeraria dell'Italia prerromana [The experience of color in the funerary painting of pre-Roman Italy] (Naples: Electa, 2001), 21-34; A. Bottini and E. Setari, Il Sarcofago delle, 2007), 62-73. 
while a Greek seizes her by the hair. ${ }^{57}$ Similarly, some reliefs show comparable poses and gestures as observed in C56, C50 (Figures 9-10) and in a fragmentary head that probably belonged to an Amazon with a Greek's hand on top $(C 321)$.

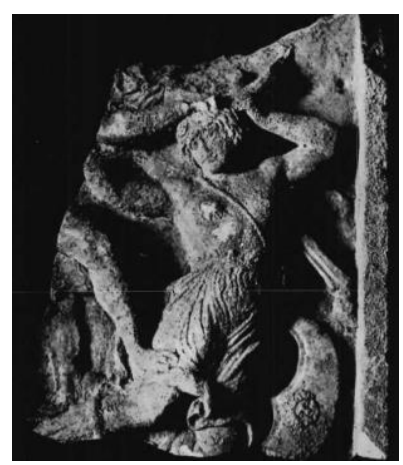

Figure 9. Budapest, relief fragment from TarantoC56. Amazonomachy Source: Carter 1975, pl. 12d.

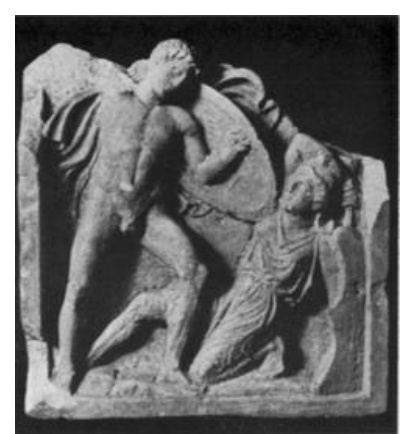

Figure 10. Taranto, metope fragment C50. Amazonomachy Source: J.C. Carter, 1975, pl. 12d.

Surviving narratives of the myth (3-4 figures) occur on a frieze depicting an Amazonomachy with Heracles (C88) dated to about 325 BC (Figure 11). ${ }^{58}$ The former is a fortunate example since the Sarcophagus of the Amazons made in South Italy for an Etruscan client- as well as the rest of the Etruscan sarcophagi portraying Amazonomachies never show a main hero. The example from Taranto, by contrast, shows an interest in a specific episode of the myth which is different from the Amazonomachies with Theseus more frequently depicted in Athens. That said, there is not enough evidence to conclude that all the Amazonomachies in the funerary naiskoi from Taranto had Heracles' as the protagonist. In this particular case, however, it is inevitable to think of possible allusions to the Amazonomachy displayed in the Mausoleum.

57. See A. Bottini and E. Setari, Il Sarcofago delle Amazzoni, 2007, fig. 19 (Greek no. 8 and Amazon no. 9).

58. MARTA inv. no. 6184. From Taranto, Arsenale area (350-300 BC), 25.3 x $79 \mathrm{~cm}$. See D. Loiacono, "Le sculture e le terrechotte archittettoniche" ["Architectural sculptures and terracotes"], in Taranto: Il Museo Archeologico, ed. E. De Juliis and D. Loiacono (Taranto: Mandese, 1985), 106-107, fig. 89. 


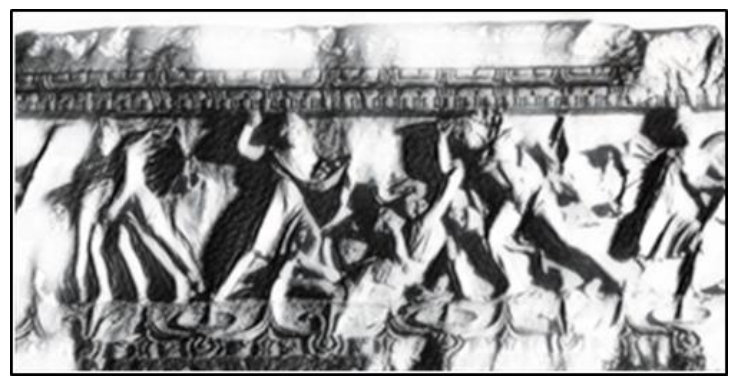

Figure 11. Taranto, Frieze Fragment C88. Amazonomachy with Heracles Source: sketch by the author from the original.

The final examples are the Amazonomachies set in the pediments of the naiskoi. This placement of the subject is perhaps the most original: the crowning of a funerary building with an Amazonomachy is, in fact, a practice without parallels elsewhere. The left remaining part of the relief pediment C92 shows a dead Amazon and a reclining male figure leaning on a rock (Figure 12). Next to him, there is an Amazon on her knees, and a standing Amazon engaged in combat. The right part of the pediment is lost, hence making the identification of the male figure in the far left challenging. In Etruscan funerary art, depictions of rocks mark the threshold between this and the other world, as they are often observed on vases, carved sarcophagi, and tomb painting. ${ }^{59}$ In the pediment, the male figure is unarmed (only the head of the defeated Amazon next to him is still visible), and he is depicted in a relaxed pose. This particular representation of the Amazon and the male figure in a rocky setting indicates that they are no longer part of the battle. Could this be a portrait of the deceased individual to whom the monument was dedicated? If so, this would be a very explicit allusion to the individual inside the tomb upon which the naiskos was built.

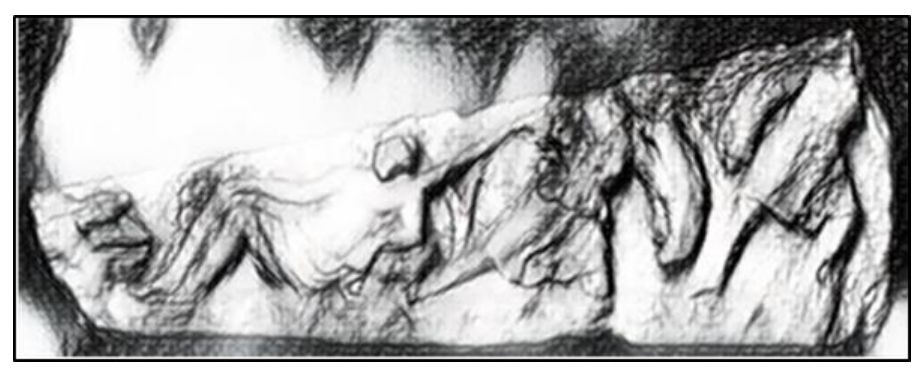

Figure 12. Taranto, pedimental relief C92 (fragment). Amazonomachy Source: sketch by the author after J.C. Carter, 1975, pl. 17a.

59. For example, in the Tomb of the Blue Demons from Tarquinia (450-400 BC) and on a red-figure calix-krater by the Turmuca Painter from Vulci (Paris, Bibl. Nat. 920, ca. 330-300 BC). On the escathological meaning of rocks in Etruscan art, see F. Roncalli, "Iconographie funéraire et topographie de l'au-delà en Étrurie" ["Funerary iconography and topography of the afterlife in Etruria"]. In Les Étrusques, les plus religieux des hommes. État de la recherchesur la religion étrusque. Actes du colloque international Grand Palais 17.-19.11.1992, ed. F. Gaultier and D. Briquel. Paris, 1997), 37-54; J.-R. Jannot, "Etruscans and the Afterworld", EtrStud 7(2000): 81-99. 
Other smaller pedimental reliefs show duels between an Amazon and a Greek. In the relief MARTA inv. 7, a Greek in his knees seems to be defeated (Figure 13); whereas, in the fragmented pediment (MARTA inv. 9 and 10), the outcome is unclear (Figure 14). The former shows some landscape elements such as small rocks and a tree. The Amazon's torso is lost, but her chiton is dynamically carved with deep, strong lines. She also wears trousers and perhaps long sleeves, thus highlighting her eastern provenance. The duel in the latter pediment is less dramatic and reflects a cruder style, as the Amazon's anatomy has a masculine touch. In general, when looking at these pediments, it is inevitable to think of similar duels between a Greek and an Amazon depicted on the short sides of some Etruscan carved sarcophagi from Tarquinia and Tuscania. $^{60}$

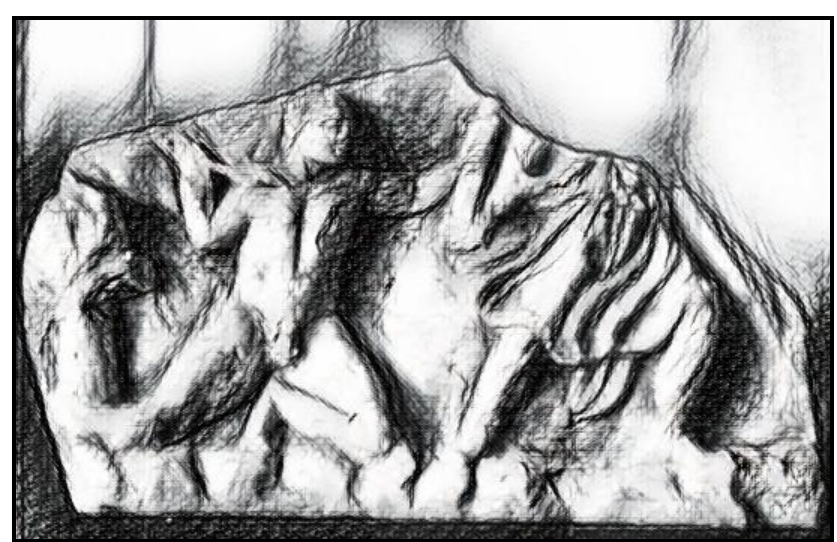

Figure 13. Taranto, MARTA inv. no. 7, Pedimental Relief Fragment. Amazonomachy

Source: sketch by the author after Bernabò-Brea, 1952, fig. 92.

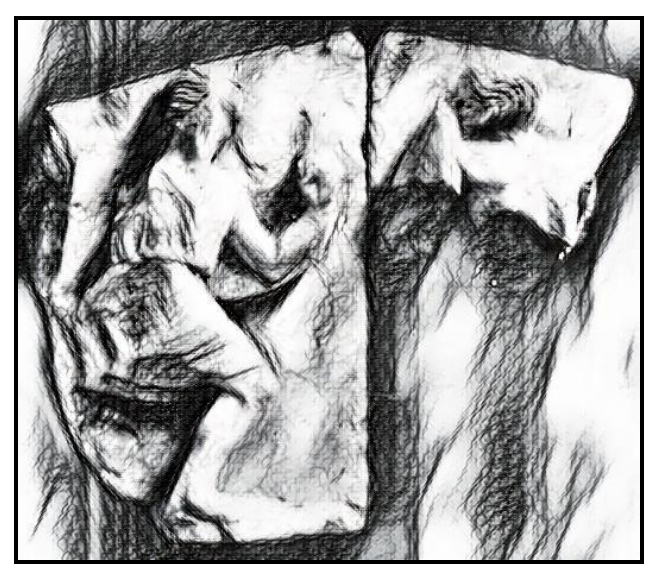

Figure 14. Taranto, MARTA inv. no. 9-10, Pedimental Relief Fragments. Amazonomachy

Source: sketch by the author after Bernabò-Brea, 1952, fig. 161.

60. Tarquinia, MAN RC 9873 (so-called Sarcophagus of the Magnate). Tuscania, MA, 86902 and (no inv. number); see A. Sgubini Moretti, Tuscania: Il museo archeologico [Tuscania: The archaeological museum] (Rome: Gazzetti, 1991), fig. 66 and 71-74 respectively. 


\section{Conclusions}

When considering Attic funerary monuments such as the Kallithea Monument, it is not impossible to conceive that the flourish of this type of monuments at Taranto might have been closely related to examples from Attica. In the Kallithea Monument and Tarantine naiskoi, the reference is to tragic myth and Classical prototypes, whether exemplified by the Parthenon or the Mausoleum at Halikarnassos, all of which exploit the Amazonomachy. No matter how provincial some of the examples from Taranto might look in their style, their compositions -some of them, original- and dramatic scenes surpass the examples from Attica. They also add landscape features to the scenes, such as rocks and trees as also observed on some Etruscan sarcophagi depicting the same subject.

To conclude, the Amazonomachies in the extant funerary monuments from Attica show that the myth was used to imprint the buildings with an eastern flavour charged with possible heroic overtones. However, when examining the subject in relation to the whole decorative programme in the Kallithea Monument with its animal friezes and free-standing sculptures, the Amazonomachy looks somehow devoid of content, giving the impression of being more decorative than representative of the actual mythic battle.

Although we have no complete examples from Taranto, the fragments featuring Amazonomachies show not only a more diverse iconography and original compositions but also new uses that are given to the subject. These include the placement of the subject in the pediment of the funerary naiskoi, and in one case probably representing the deceased individual to whom the tomb belonged. Tarantine sculptors were not only wholly familiar with the major developments and workshops of Greece, but they were also well aware of the Etruscan funerary interest in the Amazonomachy. Its popularity in Etruscan painted and carved sarcophagi, as well as in Tarantine funerary art show that the myth might have had specific eschatological connotations that were part of a common funerary iconography in pre-Roman Italy.

\section{Bibliography}

Ashmole, B. BrBr. Munich, 1937.

Aston, E. "Thessaly and Macedon at Delphi". In The Greek World in the 4th and 3rd Centuries B.C. (Electrum 19), edited by E. Drabowa. Krakow: Jagiellonian University Press, 2012.

Belli Pasqua, R. La scultura in marmo e in pietra. Catalogo del Museo Nazionale Archeologico di Taranto IV.1. Taranto: La Colomba, 1994.

Belli Pasqua, R. "Architettura funeraria a Rodi in età ellenistica: documentazione locale e forme di contatto" ["Funerary architecture in Rhodes in the Hellenistic age: local documentation and forms of contact"]. Bollettino di Archeologia on line, vol. speciale C/C7/4(2010): 43-58.

Bernabò-Brea, L. "I relieve tarantini in pietra tenera" ["Tarantine reliefs in softstone"]. RivIstArch 1(1952).

Boardman, J. Greek Sculpture: The Late Classical Period. London: Thames and Hudson, 1995. 
Bottini, A. and Setari, E. Il Sarcofago delle Amazzoni [The Amazons' Sarcophagus]. Milan: Electa, 2007.

Brecoulaki, H. L'esperienza del colore nella pittura funeraria dell'Italia prerromana [The experience of color in the funerary painting of pre-Roman Italy]. Naples: Electa, 2001.

Caianello, M. "Studi sull'arte tarantina" ["Studies on Tarantine art"]. Museion I (1923): 56-63.

Carter, J.C. The Sculpture of Taras. Transactions of the American Philosophical Society 65, no. 7. Philadelphia, 1975.

Carter, J.C. "Relief Sculptures from the Necropolis of Taranto". AJA 74, no 2(1970): 125-137.

Carpenter, T. 2009. "Prolegomenon to the Study of Apulian Red-Figure Pottery". AJA 113: 27-38.

Cerchiai, L. "Taranto". In The Greek Cities of Magna Graecia and Sicily, edited by L. Cerchiai, L. Jannelli, and F. Longo. Los Angeles: Getty Publications, 2004.

Childs, W. Greek Art and Aesthetics in the Fourth Century B.C. Princeton: Princeton University Press, 2018.

Clairmont, C. Classical Attic Tombstones. Kilchberg: Akanthus, 1993.

De Juliis, E. Taranto. Bari: Edipuglia, 2000.

De Juliis, E. "Ipogeo del Cerbero" ["The hypogeum of Cerberus"]. In Principi Imperatori Vescovi: Duemilaanni di historia a Canosa, edited by R. Cassano. Bari: Marislio, 1992.

Denoyelle, M. and Iozzo, M. La Céramique Greque d'Italie méridionale et de Sicile: Productions colonials et apparentées du VIIIe au III av. J.-C [The Greek pottery of southern Italy and Sicily: Colonial and related productions from the 8th to the 3rd BC. J.-C]. Paris: Picard, 2009.

Dohrn, T. "Die marmor Standbilder des Daochos Weihgeschenks in Delphi" ["The marble statues of Daochos' votive offerings at Delphi"]. AntP: 33-53(1968).

Edwards, C. "Lysippos." In Personal Styles in Greek Sculpture.Yale Classical Studies 30, edited by O. Palagia and J. Pollitt. Cambridge and New York: Cambridge University Press, 1996.

Ferron, J. "Le sarcophage des Amazones" ["The Amazons' sarcophagus"]. In Sarcophages de Phénicie: Sarcophages a scènes en Relief. Paris: Librarie orientaliste Paul Geuthner, 1993.

Fleischer, R. "Der Wiener Amazonensarkophag" ["The Amazons' Sarcophagus in Vienna"]. Antike Plastik 26(1998).

Gadaleta, G. La Tomba delle Danzatrici di Ruvo di Puglia [The Tomb of the Dancers from Ruvo di Puglia]. Quaderni di Ostraka 6. Loffredo, 2002.

Geominy, W. "The Daochos Monument at Delphi. The Style and Setting of a Family Portrait in Historic Dress". In Early Hellenistic Portraiture. Image, Style, Context, edited by P. Schultz and R. von den Hoff. Cambridge: Cambridge University Press, 2007.

Geominy, W. Die Florentiner Niobiden [The Florentine Niobids]. Bonn: [Theses], 1984.

Hagemajer A., K. "Becoming the 'Other': Attitudes and Practices at Attic Cemeteries". In The Cultures within Ancient Greek Culture: Contact, Conflict, Collaboration, edited by C. Dougherty and L. Kurke. Cambridge: Cambridge University Press, 2003.

Hölscher, T. "Myth, images and the typology of identity in Greek art". In Cultural Identity in the Ancient Mediterranean, edited by E. Gruen. Los Angeles, 2011.

Jannot, J.-R. "Etruscans and the Afterworld". EtrStud 7(2000): 81-99. 
Jenkins, I. Greek Architecture and Its Sculpture. London: The British Museum Press, 2006.

Jeppensen, K. "The Mausoleum at Halicarnassus: Sculptural decoration and architectural background". In Sculptors and Sculpture of Caria and the Dodecanese, edited by I. Jenkins and G. Waywell. London: The British Museum Press, 1997.

Junker, K. Interpreting the Images of Greek Myths: An Introduction. Cambridge: Cambridge University Press, 2011.

Kaltsas, N. Sculpture in the National Archaeological Museum, Athens. Los Angeles: Getty Publications, 2002.

Klumbach, H. Tarentiner Grabkunst. Reutlingen, 1937.

Knigge, U. "Marmorakroter und Fries von einem attischen Grabbau?" ["Marble acroterion and frieze from an Attic funerary building?"]. AthMitt 99(1984): 217234.

Lenormant, F. Gazzette Archéologique. Paris: A. Lévy, 1881-1882.

Lippolis, E. "Tipologie e significati del monumento funerario nella cità ellenistica. Lo sviluppo del naiskos" ["Typology and significance of the funerary monument in the Hellenistic city. The development of the naiskos"]. In Architetti, architettura e cità nel Mediterraneo orientale ellenistico. Atti del Convegno, Venezia (10-11 giugno 2005). Milan, 2007.

Lippolis, E. Arte e artigianato in Magna Grecia [Arts and crafts in Magna Graecia]. Naples: Electa, 1996.

Lippolis, E. "La tipologia dei semata" ["The typology of the semata"]. In Taranto la necropoli: Aspetti e problem della documentazione archeologica tra VII e I sec. a. $C$, edited by E. Lippolis. Catalogo del Museo Nazionale Archeologico di Taranto III.1. Taranto: La Colomba, 1994.

Lippolis, E. "La necropoli ellenistica: problemi di classificazione e cronologia dei materiali" ["The Hellenistic necropolis: problems of classification and chronology of the materials"]. In Taranto la necropoli: Aspetti e problem della documentazione archeologica tra VII e I sec. a. C., edited by E. Lippolis. Catalogo del Museo Nazionale Archeologico di Taranto III.1. Taranto: La Colomba, 1994.

Lippolis, E. "Vaste, Ipogeo delle Cariatidi: sculture architettonica del vestibolo" ["Vaste, Hypogeum of the Caryatids: architectural sculpture of the vestibule"]. In Vecchie scavi, nuovi restauratori. Catalogo della Mostra di Taranto, edited by E. Lippolis. Taranto: Scorpione, 2007.

Loiacono, D. "Le sculture e le terrechotte archittettoniche" ["Architectural sculptures and terracotes"]. In Taranto, Il Museo Archeologico, edited by E. De Juliis and D. Loiacono. Taranto: Mandese, 1985.

Mazzei, M. Arpi: L'ipogeo della Medusa e la necropolis [Arpi: The hypogeum of the Medusa and the necropolis]. Bari: Edipuglia, 1995. Steingräber

Miller, M. Athens and Persia in the Fifth Century BC: A study in cultural receptivity. Cambridge: Cambridge University Press, 1997.

Pagenstecher, R. Unteritalische Grabdenkmäler [South Italian Funerary Monuments]. Strassburg, 1912.

Palagia, O. "Commemorating the Dead: Grave Markers, Tombs, and Tomb Paintings, 400-30 BCE". In A Companion to Greek Architecture, edited by M. Miles. Wiley \& Sons, 2016.

Palagia, O. "Joseph Coleman Carter: The Sculpture of Taras". The Classical Review 28, no. 01(1978):189. 
Picón, C. "Sculptural Styles of Magna Graecia". In Magna Graecia: Greek art from South Italy and Sicily, edited by M. Bennett, A. Paul and M. Iozzo. The Cleveland Museum of Art. New York and Manchester: Hudson Hills, 2002.

Pontrandolfo, A., Prosco, G., Mugione, E., Lafage, F. "Semata e naiskoi nella ceramica italota" ["Semata and naiskoi in Italote ceramics"]. AION 10(1988): 181-202.

Riedemann Lorca, V. Greek Myths Abroad: A Comparative Regional Study of Their Funerary Uses in Apulia and Etruria. DPhil Dissertation, University of Oxford, 2016.

Ridgway, B. Fourth-Century Styles in Greek Sculpture. Madison: The University of Wisconsin Press, 1997.

Ridgway, B. Hellenistic Sculpture I, 331-200 BC. Bristol: Bristol Classical Press, 1990.

Roncalli, F. "Iconographie funéraire et topographie de l'au-delà en Étrurie" ["Funerary iconography and topography of the afterlife in Etruria"]. In Les Étrusques, les plus religieux des hommes. État de la recherche sur la religion étrusque. Actes du colloque international Grand Palais 17.-19.11.1992, edited by F. Gaultier and D. Briquel. Paris, 1997.

Schiering, W. "Zum Amazonenfries des Maussoleums in Halikarnass" ["On the Amazons' Frieze from the Mausoleum at Halikarnassos"]. JdI 90 (1975): 132133.

Schmaltz, B. Griechische Grabreliefs [Greek Grave Reliefs]. Darmstadt, 1983.

Scholl, A. "Hades and Elyseon - images of the afterlife in Classical Athens". In Exploring Ancient Sculpture: Essays in Honour of Geoffrey Waywell, edited by F. Macfarlane and C. Morgan. London: Institute of Classical Studies, 2010.

Scholl, A. "Der Perser und die skythischen Bogenschütze zu dem Kerameikos" ["The Persian and the Skythian archers in the Kerameikos"]. JDAI 115 (2001):79-112.

Sgubini Moretti, A. Tuscania: Il museo archeologico [Tuscania: The archaeological museum]. Rome: Gazzetti, 1991.

Steingräber, S. "La pittura funeraria della Daunia: elementi iconografici caratteristici nel contesto della pittura apula, magnogreca a miditerranea preromana (IV-III a.C.)" ["The funerary painting from Daunia: common iconographic elements in the context of Apulian, Magna Graecian and pre-Roman painting"]. In Storia e Archeologia della Daunia: Atti delle Giornate di studio (Foggia 19-21 maggio 2005), edited by G. Volpe, M. Strazzulla and D. Leone. Bari: Edipuglia, 2008.

Steingräber, S. Arpi-Apulien-Makedonien. Studien zum unteritalischen Grabwesen in hellenistischer Zeit [Arpi-Apulia-Macedonia. Studies on south Italian tomb structures in Hellenistic times]. Mainz: Phillip von Zabern, 2000.

Steinhauer, G. The Archaeological Museum of Piraeus. Athens: Latsis Group, 2001.

Stewart, A. Greek Sculpture: An Exploration. New Haven \& London: Yale University Press, 1990.

Todisco, L. "Vasi con naiskoi tra Taranto e centri italici" ["Vases with naiskoi between Taranto and Italic centers"]. In Inszenierung von Identitäten: Unteritalische Vasenmalerei zwischen Griechen und Indigenen, edited by U. Kästner and S. Schmidt. Munich: Verlag der Bayerischen Akademie der Wissenschaften, 2018.

Todisco, L. "La tomba delle Danzatrici di Ruvo" ["The Tomb of the Dancers from Ruvo"]. In Mitti Greci dalla Magna Graecia al collezionismo, edited by G. Sena Chiesa. Milano: Electa, 2005.

Trendall, A.D. The Red Figure Vases of South Italy and Sicily. London: Thames \& Hudson, 1989.

Tsirivakos, E. "Kallithea: Ergebnisse der Ausgrabung" ["Kallithea: Results of the excavation"]. AAA 4, no. 1(1971): 108-110.

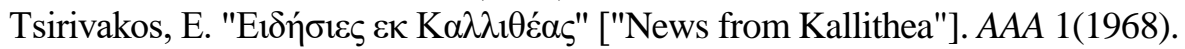


Van der Meer, L.B. Myths and More: On Etruscan Stone Sarcophagi (c. 350- c. 200 B.C.). Louvain: Dudley, 2004. 
